\title{
INCREASING THE EFFFICINCY OF EI-SALAM CANAL PROJECT USING DATA DRIVEN WATER QUALITY MODELS
}

\author{
Mohamed, Dalia, Sh. ${ }^{(1)}$; Korany, E. A. ${ }^{(2)}$ and El-Saadi, A. M. Kh. ${ }^{(1)}$ \\ 1) Drainage Research Institute, National Water Research Center \\ 2) Hydrogeology Department, Faculty of Science, Ain Shams University
}

\begin{abstract}
The Egyptian Government started the El-Salam Canal Project (ESCP) for the reclamation of an estimated 620,000 feddans of desert land in north sinia. It receives fresh water from Damietta Branch of the River Nile and agricultural drainage water from Lower Serw, Farsqur and Bahr Hadus drains. The present study aims to increase the efficiency of the project and assess the quality of water in the feeding sources and compare it to the current/future operating conditions. The results are obtained by developing a numerical/data driven models to simulate the project working conditions using real field data. Then, an alternative working scenarios are proposed. The water quality data were collected monthly for the period 2003/2015 different water quality parameters are considered. Water samples were collected from 8 locations along the main reach of El-Salam canal and the feeding drains. They were analyzed for some water quality parameters such as TDS, BOD.

The results indicate that in months of high demand, it is possible to increase the discharges to feed ESCP from Farsqur, Lower Serw or Hadus drains (if needed/available) assuming having their current levels of concentrations. This will not significantly deteriorate the canal water in relation to the water quality parameters of TDS and BOD.
\end{abstract}

Keywords: El-Salam Canal, Regression model, Drainage Water Reuse, Water Quality. 
J. Environ. Sci.

Institute of Environmental Studies and Research - Ain Shams University

\section{INTRODUCTION}

Egypt has been practicing drainage water reuse since the 1930s (NAWQAM, 1999). The Egyptian Ministry of Water Resources and Irrigation (MWRI) took the responsibility to divert considerable amounts of drainage water to be mixed with fresh Nile water with different mixing ratios (up to 1:1) to irrigate newly reclaimed areas. The El-Salam Canal Project (ESCP) as shown in (figure 1) is one of the mega projects that aims at irrigating (620,000 feddan) in North Sinai.

At the onset of the ESCP, it was assumed that the total drainage water available from Hadus and Lower Serw drains is around 3.45 milliard m3/year ( 2.72 and 0.73 milliard m3/year respectively). This policy employs a minimum of $10 \%$ from the available drainage water in the Lower Serw drain (0.07 milliard m3/year) and a minimum of $20 \%$ in the Hadus drain ( 0.54 milliard m3/year) to continue to flow towards Lake Manzala to protect its ecosystem. According to this proposal always 2.2 milliard m3/year from drainage water are guaranteed for the project (DRI, 1985).

The project represents great opportunities of employment and builds new communities that can attract people out of the overpopulated areas in the Nile valley. It increases agriculture production to sustain food security (El-Sayed, 2006). However, the impacts of using drainage water as a low quality water are of great environmental concern. National Water Quality Monitoring Network (NWQMN) is established by the Egyptian ministry of water resources and irrigations to monitor the seasonal variation and possible water quality trends in the water reaches. 


\section{OBJETIVES}

The present study used numerical/data driven models to evaluate different water quality and management scenarios in order to choose the optimal one. The main objective includes the following:

- Investigate the possibility of using numerical/data driven modeling to simulate the project components to ensure environmentally sound management actions.

- Propose an alternative scenarios to take advantage of the available water resources from the drains in the project area for the best operational practice of the project that is acceptable from the environmental perspective.

\section{MATERIAL \& METHODS}

The field data are collected from eight locations. Fig (2) illustrated the five sites that sampled at the main stream of the canal. They include ; El-Salam Pump Station No. 1, El-Salam Pump Station No. 2, and Syphon at Suez Canal, ElSalam Pump Station No. 4, and after mixing with the Bahr Hadus drainage water. The other three sampling sites in the main feeders of the canal (El-Salam Intake from the Damietta Branch of the River Nile, El-Salam Pump Station No. 3 in the outfall of Bahr Hadus drain and the Lower Serw drain Outfall. The sampling locations are presented in Table (1) as described in (DRI, 1995), (DRI, 1997), (DRI, 2005) and (DRI, 2015). 
J. Environ. Sci.

Institute of Environmental Studies and Research - Ain Shams University

Table (1): Monitoring stations along El-Salam canal and feeding drains

\begin{tabular}{|c|c|}
\hline $\begin{array}{c}\text { Location } \\
\text { Code }\end{array}$ & Description \\
\hline \hline EI21 & El-Salam Intake from the Damietta Branch of the River Nile \\
\hline EF01 & Farsqur Pump Station \\
\hline EI18 & before mixing with Lower Serw drain \\
\hline ES02 & The Lower Serw drain Outfall \\
\hline ESL01 & Salam canal after mixing between Damietta branch and Lower Serw P.S \\
\hline ESL02 & before mixing with Hadus drain \\
\hline ESL03 & Hadus drain before mixing with El Salam canal \\
\hline ESL07 & outlet to the siphon of Suez Canal \\
\hline
\end{tabular}

Representative water samples were collected and analyzed according to the standard methods for the examination of water and Wastewater, (APHA, 1995). The modeling process consider two water quality parameters (WQPs) namely; Total Dissolved Salts (TDS), Biological Oxygen Demand (BOD). These parameters are indicators for almost all types of common pollutants in the Egyptian surface water representing agricultural and domestic sources of pollution in Egypt.

The data of water quality parameters WQPs for the period (July 2003 August 2013), as shown in table (2), were used to construct the regression model. Similar data for the water year 2014/2015 are used for model validation process. 
Table (2): The average concentration of the Water Quality Parameters (WQPs) measured at ESCP.

\begin{tabular}{|c|c|c|c|c|c|c||}
\hline $\begin{array}{c}\text { Location } \\
\text { Code }\end{array}$ & Description & $\begin{array}{c}\text { TDS } \\
(\mathbf{m g} / \mathbf{l})\end{array}$ & $\begin{array}{c}\text { BOD } \\
(\mathbf{m g} / \mathbf{l})\end{array}$ & $\begin{array}{c}\text { DO } \\
(\mathbf{m g} / \mathbf{l})\end{array}$ & $\begin{array}{c}\text { Fe } \\
(\mathbf{m g} / \mathbf{l})\end{array}$ & $\begin{array}{c}\text { COD } \\
(\mathbf{m g} / \mathbf{l})\end{array}$ \\
\hline \hline EI21 & $\begin{array}{c}\text { El-Salam Intake from the } \\
\text { Damietta Branch of the River } \\
\text { Nile }\end{array}$ & 522 & 15 & 5.4 & 0.74 & 19.5 \\
\hline EF01 & Farsqur Pump Station & 924.11 & 23 & 3.27 & 0.7 & 32.15 \\
\hline EI18 & $\begin{array}{c}\text { before mixing with Lower Serw } \\
\text { drain }\end{array}$ & 478 & 12.4 & 5.7 & 0.61 & 17.7 \\
\hline ES02 & The Lower Serw drain Outfall & 848.59 & 16.18 & 4.3 & 0.63 & 26.36 \\
\hline ESL01 & $\begin{array}{l}\text { Salam canal after mixing between } \\
\text { Damietta branch and Lower Serw } \\
\text { P.S }\end{array}$ & 630.63 & 13.165 & 5.02 & 0.723 & 23 \\
\hline ESL03 & $\begin{array}{c}\text { Hadus drain before mixing with } \\
\text { El Salam canal }\end{array}$ & 1402.25 & 20 & 2.91 & 0.72 & 26.47 \\
\hline ESL07 & outlet to the siphon of Suez Canal & 723.29 & 11 & 4.16 & .0 .67 & 16.72 \\
\hline
\end{tabular}

The El-Salam Canal is simulated using three data driven models for each water quality parameter. The Models simulate the canal reach from its intake at Damietta Branch until the point just before the Suez Canal Syphon. The mathematical expression for the model can be simplified as a dependent variable (ESL07) to be a function of the independent four variables; (EI21), (EF01), (ES02) and (ESL03). The Forced entry modeling technique (or "Enter" method as it is known in SPSS) is used to simulate the previous model representing the ESCP. In this method, all predictors are forced into the model simultaneously. The selection for this method was mainly due to good theoretical reasons for including the chosen predictors as main water sources for ESCP. In addition, some researchers believe that this method is the only appropriate method for theory testing (Studenmund \& Cassidy, 1987). 
Modeling Scenarios: Two main scenarios (A and B) were adopted to investigate the possible responses to water quality changes in the ESCP system. These scenarios include the followings:

- Scenario A (Water Quality Deterioration): This scenario investigates the case of increasing the water quality variables for each water source by $50 \%$ and $75 \%$ from its mean (2003 - 2013). When using the model to estimate the influence of a certain water source, the other source/s was/were assumed to be constant (taken as the mean value/s for the measured data from 2003 to 2013)

- Scenario B (Water Quality Development): This scenario investigates the case of decreasing the water quality variables for each water source by $50 \%$ and $75 \%$ from the mean (2003 - 2013).

\section{RESULTS AND DISCUSSION}

Table (3) shows, the F-ratio (40.133) is very unlikely to have happened by chance $(p<.001)$. i.e, the model is an adequate fit at the $1 \%$ level of significance.

Table (3): Analysis of Variance (ANOVA) test for the regression TDS model

\begin{tabular}{|c|c|c|c|c|c|}
\hline Model & Sum of Squares & df & Mean Square & F & Sig. \\
\hline Regression & 7352167.717 & 4 & 1838041.929 & 40.133 & $0.000 \mathrm{~b}$ \\
\hline Residual & 6411871.690 & 140 & 45799.083 & & \\
\hline Total & 13764039.407 & 144 & & & \\
\hline
\end{tabular}

The mathematical expression for TDS model can be expressed as:

$($ ESL07-TDS $)=-\mathbf{0 . 6 5} *($ EI21-TDS $)+0.286 *($ EF01-TDS $)+0.039 *($ ES02-TDS $)$

$+0.135 *($ ESL03-TDS $)+579.769 \ldots \ldots . . . . .$. Eq. $(1)$ 
Table (4) provides some measures of whether there is collinearity in the data. Specifically, it provides the Variance Inflation Factor (VIF) and tolerance, the VIF values $(1.18,1.135,1.063$ and 1.055) are well below 10 and the tolerance statistics $(0.847,0.881,0.941$ and 0.948$)$ are well above 0.2 ; Therefore, we can safely conclude that there is no collinearity within the model data.

Table (4): Parameters of TDS model

\begin{tabular}{|c|c|c|c|c|c|c|c||}
\hline \multirow{2}{*}{ Model } & \multicolumn{2}{|c|}{$\begin{array}{c}\text { Unstandardized } \\
\text { Coefficients }\end{array}$} & $\begin{array}{c}\text { Standardized } \\
\text { Coefficients }\end{array}$ & \multirow{2}{*}{ t } & \multirow{2}{*}{ Sig. } & \multicolumn{2}{|c|}{$\begin{array}{c}\text { Collinearity } \\
\text { Statistics }\end{array}$} \\
\cline { 2 - 6 } \cline { 7 - 9 } & B & $\begin{array}{c}\text { Std. } \\
\text { Error }\end{array}$ & Beta & & & Tolerance & VIF \\
\hline \hline (Constant) & 579.760 & 93.853 & & 6.177 & 0.000 & & \\
\hline EI21_TDS & -0.650 & 0.060 & -0.682 & -10.886 & 0.000 & 0.847 & 1.180 \\
\hline EF01_TDS & 0.286 & 0.076 & 0.230 & 3.738 & 0.000 & 0.881 & 1.135 \\
\hline ES02_TDS & 0.039 & 0.046 & 0.051 & 0.856 & 0.394 & 0.941 & 1.063 \\
\hline ESL03_TDS & 0.135 & 0.037 & 0.218 & 3.680 & 0.000 & 0.948 & 1.055 \\
\hline
\end{tabular}

a. Dependent Variable: ESL07_TDS TDS Model

Figure (3) represents the Normal Probability Plot for Residuals. It shows up little deviations from normality. However, the residuals of TDS model, are very near to behave as normally distributed data and very near to meet the assumption. In addition the figure (4) represents the plot of standardized residuals against standardized predicted values and look like a random array of dots evenly dispersed around zero.

BOD Model: The $\mathrm{R}$ value is 0.538 that is the multiple correlation between (ESL07-BOD) and (ESL03-BOD, ES02-BOD, EF01-BOD and EI21-BOD). The $\mathrm{R} 2$ value is 0.290, which means that (ESL03-BOD, ES02-BOD, EF01-BOD and EI21-BOD).accounts for $29 \%$ of the variation in (ESL07-BOD). The difference 
between adjusted R2 and the value of R2 is $0.270-0.290=-0.02$ (about 2\%). indicating that the cross-validity of this model is good.

The F-ratio of 14.901, which is significant with a probability less than 0.001. This means that there is a significant difference by adding the predictors to the model. The Durbin-Watson statistic is 1.551 , which is relatively close to 2 that the assumption has almost been met. This means that the model is an adequate fit at the $1 \%$ level of significance.

Table (5) represents the estimates for the b-values that indicate the individual contribution of each predictor to the model.

Table (5): Parameters of BOD model

\begin{tabular}{|c|c|c|c|c|c|c|c||}
\hline \multirow{2}{*}{ Model } & \multicolumn{2}{|c|}{$\begin{array}{c}\text { Unstandardized } \\
\text { Coefficients }\end{array}$} & $\begin{array}{c}\text { Standardized } \\
\text { Coefficients }\end{array}$ & \multirow{2}{*}{$\mathbf{t}$} & \multirow{2}{*}{ Sig. } & \multicolumn{2}{|c|}{$\begin{array}{c}\text { Collinearity } \\
\text { Statistics }\end{array}$} \\
\cline { 2 - 5 } & $\mathbf{B}$ & $\begin{array}{c}\text { Std. } \\
\text { Error }\end{array}$ & Beta & & & Tolerance & VIF \\
\hline (Constant) & 5.880 & 0.819 & & 7.179 & 0.000 & & \\
\hline EI21_BOD & 0.084 & 0.045 & 0.183 & 1.870 & 0.063 & 0.509 & 1.965 \\
\hline EF01_BOD & 0.099 & 0.039 & 0.237 & 2.558 & 0.012 & 0.567 & 1.764 \\
\hline ES02_BOD & 0.020 & 0.027 & 0.062 & 0.766 & 0.445 & 0.741 & 1.349 \\
\hline ESL03_BOD & 0.062 & 0.034 & 0.176 & 1.855 & 0.066 & 0.539 & 1.855 \\
\hline \hline
\end{tabular}

Consequently, the mathematical expression for BOD model, can be expressed as:

$($ ESL07-BOD $)=0.084 *($ EI21-BOD $)+0.099 *($ EF01-BOD $)+0.02 *($ ES02-BOD $)$ $+0.062 *($ ESL03-BOD $)+5.88$....... Eq. (2)

It also provides Variance Inflation Factor (VIF) and tolerance as measures of collinearity in the data. For the BOD model, the VIF values $(1.965,1.764$, 1.349 and 1.855$)$ are well below 10 and the tolerance statistics $(0.509,0.567$, 
0.741 and 0.539 ) are well above 0.2 ; therefore, we can safely conclude that there is no collinearity within the model data.

In order to test the normality of residuals, the Normal Probability Plot for Residuals is presented in figure (5). It shows up little deviations from normality. However, the residuals of BOD model, are near to behave as normally distributed data.

Figure (6) shows the plot of standardized residuals against standardized predicted values for BOD model, it can be easily concluded that the points are randomly and evenly dispersed throughout the plot.

Model Verification: Figures (7 and 8) show that the developed regression equations for the model proved to perform well in predicting the WQPs (TDS, BOD) and simulating pretty good the third reach from ESCP.

\section{Modeling Scenarios:}

TDS Model: Tables (6) and (7) present the possible responses to TDS changes in the ESCP system and their influences on the TDS concentrations at the monitoring location (Dependent variable) ESL07. The TDS model results indicate the followings:

\section{Scenario A (Water Quality Deterioration):}

- The TDS concentration at ESL07 will improved by $16.3 \%$ in case of $50 \%$ deterioration in water quality of EI21. However, in case of deterioration in EF01, ES02 and ESL03 by 50\%, it will lead to a deterioration of 16\%, 2.2\% and $12 \%$, respectively at ESL07.

- The TDS concentration at ESL07 will improved by $24.5 \%$ in case of $75 \%$ deterioration in water quality at EI21. However, in case of deterioration in 
J. Environ. Sci.

Institute of Environmental Studies and Research - Ain Shams University

EF01, ES02 and ESL03 by 75\%, it will lead to a deterioration of $24.1 \%, 3.4 \%$ and $18 \%$ respectively at ESL07.

Table (6): TDS Model Scenario A

\begin{tabular}{|c|c|c|c|c|c|c|c|}
\hline Scenarios & EI21-TDS & EF01-TDS & ES02-TDS & ESL03-TDS & $\begin{array}{l}\text { Mean ESL07 - } \\
\text { TDS(2003-2013) }\end{array}$ & $\begin{array}{c}\text { Model } \\
\text { (ESL07-TDS) }\end{array}$ & $\begin{array}{c}\% \text { of } \\
\text { Change }\end{array}$ \\
\hline Mean(2003-2013) & 404.28 & 902.48 & 922.79 & 1433.19 & 815.22 & 804.57 & \\
\hline Mean El21(1+50\%) & 606.42 & 902.48 & 922.79 & 1433.19 & 815.22 & 673.17 & $-16.30 \%$ \\
\hline Mean EF01(1+50\%) & 404.28 & 1353.72 & 922.79 & 1433.19 & 815.22 & 933.62 & $16.00 \%$ \\
\hline Mean ES02(1+50\%) & 404.28 & 902.48 & 1384.19 & 1433.19 & 815.22 & 822.56 & $2.20 \%$ \\
\hline Mean ESL03(1+50\%) & 404.28 & 902.48 & 922.79 & 2149.79 & 815.22 & 901.31 & $12.00 \%$ \\
\hline Mean EI21(1+75\%) & 707.49 & 902.48 & 922.79 & 1433.19 & 815.22 & 607.48 & $-24.50 \%$ \\
\hline Mean EF01(1+75\%) & 404.28 & 1579.34 & 922.79 & 1433.19 & 815.22 & 998.15 & $24.10 \%$ \\
\hline Mean ES02(1+75\%) & 404.28 & 902.48 & 1614.88 & 1433.19 & 815.22 & 831.56 & $3.40 \%$ \\
\hline Mean ESL03(1+75\%) & 404.28 & 902.48 & 922.79 & 2508.08 & 815.22 & 949.68 & $18.00 \%$ \\
\hline
\end{tabular}

\section{Scenario B (Water Quality Improvement):}

- The TDS concentration at ESL07 will deteriorated by $16.3 \%$ in case of $50 \%$ improvement in water quality at EI21, however, in case of improvement in EF01, ES02 and ESL03 by 50\%, it will lead to an improvement by $16 \%$, $2.2 \%$ and $12 \%$ respectively at ESL07.

- The TDS concentration at ESL07 will deteriorate by $24.5 \%$ in case of $75 \%$ improvement in water quality at EI21, however, in the case of improvement in EF01, ES02 and ESL03 by $75 \%$ will lead to an improvement by $24.1 \%$, $3.4 \%$ and $18 \%$ respectively at ESL07. 
Table (7): TDS Model Scenario B

\begin{tabular}{|c|c|c|c|c|c|c|c|}
\hline Scenarios & EI21-TDS & EF01-TDS & ES02-TDS & ESL03-TDS & $\begin{array}{c}\text { Mean ESL07- } \\
\text { TDS(2003-2013) }\end{array}$ & $\begin{array}{c}\text { Model } \\
\text { (ESL07-TDS) }\end{array}$ & $\begin{array}{c}\% \text { of } \\
\text { Change }\end{array}$ \\
\hline Mean(2003-2013) & 404.28 & 902.48 & 922.79 & 1433.19 & 815.22 & 804.57 & \\
\hline Mean El21(1-50\%) & 202.14 & 902.48 & 922.79 & 1433.19 & 815.22 & 935.96 & $16.30 \%$ \\
\hline Mean EF01(1-50\%) & 404.28 & 451.24 & 922.79 & 1433.19 & 815.22 & 975.51 & $-16.00 \%$ \\
\hline Mean ES02(1-50\%) & 404.28 & 902.48 & 461.6 & 1433.19 & 815.22 & 786.57 & $-2.20 \%$ \\
\hline Mean ESL03(1-50\%) & 404.28 & 902.48 & 922.79 & 716.6 & 815.22 & 707.83 & $-12.00 \%$ \\
\hline & & & & & & & \\
\hline Mean El21(1-75\%) & 101.07 & 902.48 & 922.79 & 1433.19 & 815.22 & 1001.65 & $24.50 \%$ \\
\hline Mean EF01(1-75\%) & 404.28 & 225.62 & 922.79 & 1433.19 & 815.22 & 610.98 & $-24.10 \%$ \\
\hline Mean ES02(1-75\%) & 404.28 & 902.48 & 230.7 & 1433.19 & 815.22 & 777.57 & $-3.40 \%$ \\
\hline Mean ESL03(1-75\%) & 404.28 & 902.48 & 922.79 & 358.3 & 815.22 & 959.46 & $-18.00 \%$ \\
\hline
\end{tabular}

BOD Model: Table (8) and (9) present the possible responses to BOD changes in the ESCP system and their influences on the BOD concentrations at the monitoring location (Dependent variable) ESL07. The BOD model results indicate the followings:

\section{Scenario A (Water Quality Deterioration):}

- The BOD concentration at ESL07 will deteriorate by $4.1 \%$ in case of $50 \%$ deterioration in water quality of EI21, however, in case of deterioration in EF01, ES02 and ESL03 by 50\%, it will lead to a deterioration by $10 \%, 1.1 \%$ and $4.7 \%$ respectively at ESL07.

- The BOD concentration at ESL07 will deteriorate by $6.1 \%$ in case of $75 \%$ deterioration in water quality of EI21, however, in case of deterioration in EF01, ES02 and ESL03 by $75 \%$, it will lead to a deterioration by $15 \%, 2.5 \%$ and $7.1 \%$ respectively at ESL07. 
J. Environ. Sci.

Institute of Environmental Studies and Research - Ain Shams University

Table (8): BOD Model Scenario A

\begin{tabular}{||c|c|c|c|c|c|c|c|}
\hline Scenarios & EI21-BOD & EF01-BOD & ES02-BOD & ESL03-BOD & $\begin{array}{c}\text { Mean ESL07-BOD } \\
\text { (2003-2013) }\end{array}$ & $\begin{array}{c}\text { Model } \\
\text { (ESL07-BOD) }\end{array}$ & $\begin{array}{c}\text { \% of } \\
\text { Change }\end{array}$ \\
\hline Mean(2003-2013) & 9.55 & 20.08 & 16.19 & 15.13 & 9.61 & 9.93 & \\
\hline Mean El21(1+50\%) & 14.33 & 20.08 & 16.19 & 15.13 & 9.61 & 10.33 & $4.10 \%$ \\
\hline Mean EF01(1+50\%) & 9.55 & 30.12 & 16.19 & 15.13 & 9.61 & 10.93 & $10.00 \%$ \\
\hline Mean ES02(1+50\%) & 9.55 & 20.08 & 24.29 & 15.13 & 9.61 & 10.09 & $1.70 \%$ \\
\hline Mean ESL03(1+50\%) & 9.55 & 20.08 & 16.19 & 22.7 & 9.61 & 10.4 & $4.70 \%$ \\
\hline & & & & & & & \\
\hline Mean El21(1+75\%) & 16.71 & 20.08 & 16.19 & 15.13 & 9.61 & 10.53 & $6.10 \%$ \\
\hline Mean EF01(1+75\%) & 9.55 & 35.14 & 16.19 & 15.13 & 9.61 & 11.42 & $15.00 \%$ \\
\hline Mean ES02(1+75\%) & 9.55 & 20.08 & 28.33 & 15.13 & 9.61 & 10.17 & $2.50 \%$ \\
\hline Mean ESL03(1+75\%) & 9.55 & 20.08 & 16.19 & 26.48 & 9.61 & 10.64 & $7.10 \%$ \\
\hline
\end{tabular}

\section{Scenario B (Water Quality Improvement):}

- The BOD concentration at ESL07 will improve by $4 \%$ in case of $50 \%$ improvement in water quality of EI21, However, in case of improvement in EF01, ES02 and ESL03 by 50\%, it will lead to an improvement by $10 \%$, $1.6 \%$ and $4.7 \%$ respectively at ESL07.

- The BOD concentration at ESL07 will improve by $6 \%$ in case of $75 \%$ improvement in water quality of EI21, However, in case of improvement in EF01, ES02 and ESL03 by $75 \%$, it will lead to an improvement by $15 \%$, $2.4 \%$ and $7.1 \%$ respectively at ESL07. 
Table (9): BOD Model Scenario B

\begin{tabular}{|c|c|c|c|c|c|c|c|}
\hline Scenarios & El21-BOD & EF01-BOD & ES02-BOD & ESL03-BOD & $\begin{array}{c}\text { Mean ESL07-BOD } \\
\text { (2003-2013) }\end{array}$ & $\begin{array}{c}\text { Model } \\
\text { (ESL07-BOD) }\end{array}$ & $\begin{array}{c}\% \text { of } \\
\text { Change }\end{array}$ \\
\hline Mean(2003-2013) & 9.55 & 20.08 & 16.19 & 15.13 & 9.61 & 9.93 & \\
\hline Mean El21(1-50\%) & 4.78 & 20.08 & 16.19 & 15.13 & 9.61 & 9.53 & $-4.00 \%$ \\
\hline Mean EF01(1-50\%) & 9.55 & 10.04 & 16.19 & 15.13 & 9.61 & 8.94 & $-10 \%$ \\
\hline Mean ES02(1-50\%) & 9.55 & 20.08 & 8.1 & 15.13 & 9.61 & 9.77 & $-1.60 \%$ \\
\hline Mean ESL03(1-50\%) & 9.55 & 20.08 & 16.19 & 7.57 & 9.61 & 9.46 & $-4.70 \%$ \\
\hline & & & & & & & \\
\hline Mean El21(1-75\%) & 2.39 & 20.08 & 16.19 & 15.13 & 9.61 & 9.33 & $-6.00 \%$ \\
\hline Mean EF01(1-75\%) & 9.55 & 5.02 & 16.19 & 15.13 & 9.61 & 8.44 & $-15.00 \%$ \\
\hline Mean ES02(1-75\%) & 9.55 & 20.08 & 4.05 & 15.13 & 9.61 & 9.69 & $-2.40 \%$ \\
\hline Mean ESL03(1-75\%) & 9.55 & 20.08 & 16.19 & 3.78 & 9.61 & 9.23 & $-7.10 \%$ \\
\hline
\end{tabular}

\section{CONCLUSION AND RECOMMENDATION}

The present study is conducted to simulate the water quality parameters TDS and BOD through El-Salam canal in Egypt using regression based models by using monthly data collected during the period 2003-2013. The followings results are obtained.

- The developed regression based models are performed well in predicting the examined water quality parameters along the canal system.

- Two main scenarios for water quality improvement and deterioration are tested in order to estimate the optimum mixing ratio of drainage to fresh water for the environmental management of El-Salam project without exceeding the water quality threshold limits $(1000 \mathrm{mg} / \mathrm{l}$ for TDS, $15 \mathrm{mg} / \mathrm{l}$ for BOD).

- Concerning TDS, the obtained results indicate that an increasing the discharges to ESCP from Farsqur drain up to $75 \%$ or increasing from Lower Serw or Hadus drains up to $75 \%$ (if needed/available) assuming having their 
current levels of TDS concentrations will not significantly deteriorate the canal water. In these cases, TDS concentrations at ESL07 will be very near to $1000 \mathrm{mg} / \mathrm{l}$.

- Concerning BOD, it is possible to increase the discharges from Farsqur, ElSerw or Hadus drains to ESCP up to $75 \%$ (if needed/available) assuming having their current levels of BOD .

\section{REFERENCES}

APHA (American Public Health Association), (1998) "Standard methods for the examination of water and wastewater". 20th edition.

DRI (Drainage Research Institute).(1985): "Estimation of available water for the El-Salam Canal Project, Reuse of drainage water project", Report 3.

DRI (Drainage Research Institute), (1995): "Reuse of Drainage Water in the Nile Delta: Monitoring, Modeling and Analysis", Report no. 50, DRI and SC-DLO, Cairo, Egypt.

DRI (Drainage Research Institute),(1997): “Drainage Water Irrigation Project”, Final Report, DRI and Louis Berger Int., Cairo, Egypt.

DRI (Drainage Research Institute),(2005): “Drainage Water Status in the Nile Delta, Year Book 2005/2006.Technical Report No.76.

DRI (Drainage Research Institute) (2015): "Drainage Water Status in the Nile Delta, National Water Quality and Availability Management Project”. Report No. 83.

El-Sayed M. A. Rassoul (2006): "Prospects OF Water Reuse In Egypt ",Tenth International Water Technology Conference, IW TC10 2006, Alexandria, Egypt

NAWQAM (National Water Quality and Availability Management), (1999): "Drainage Water Reuse and Pilot Schemes", Inception Report, vol. 4 (Draft), Cairo Egypt. 
Studenmund, A. H., \& Cassidy, H. J.(1987):. "Using econometrics: a practical guide. Boston": Little Brown.

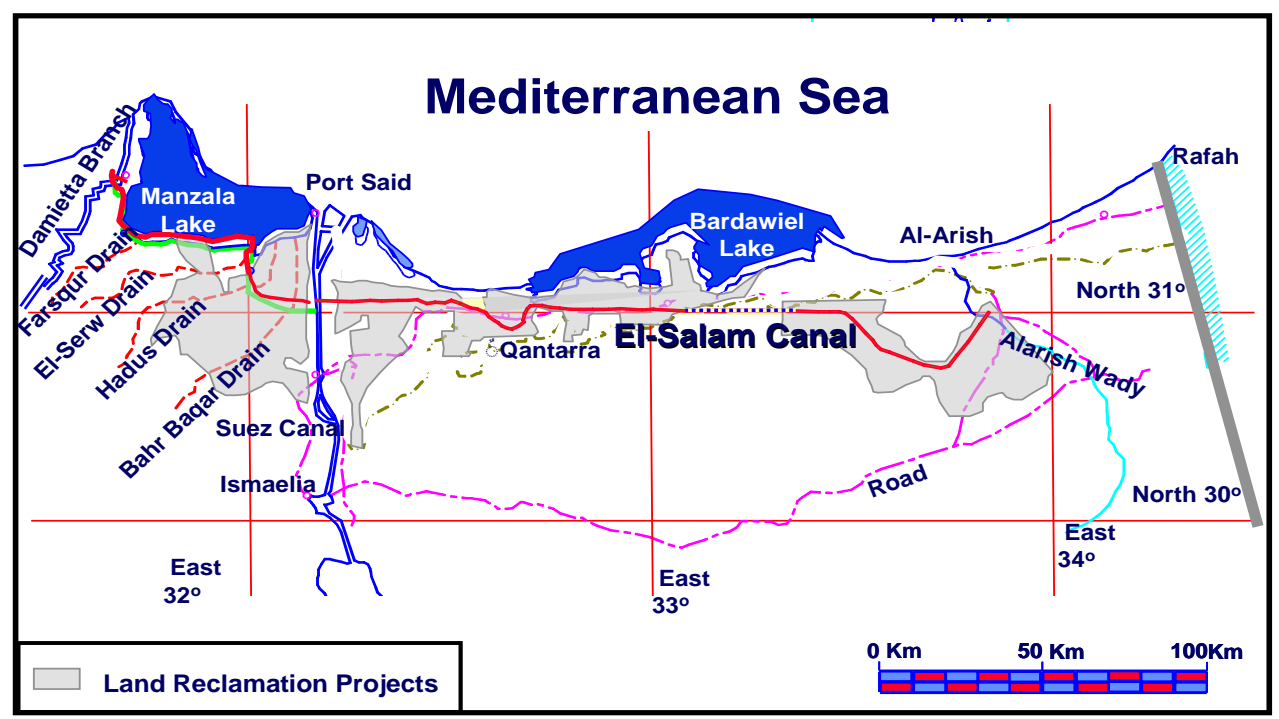

Figure (1): El Salam Canal Project Layout

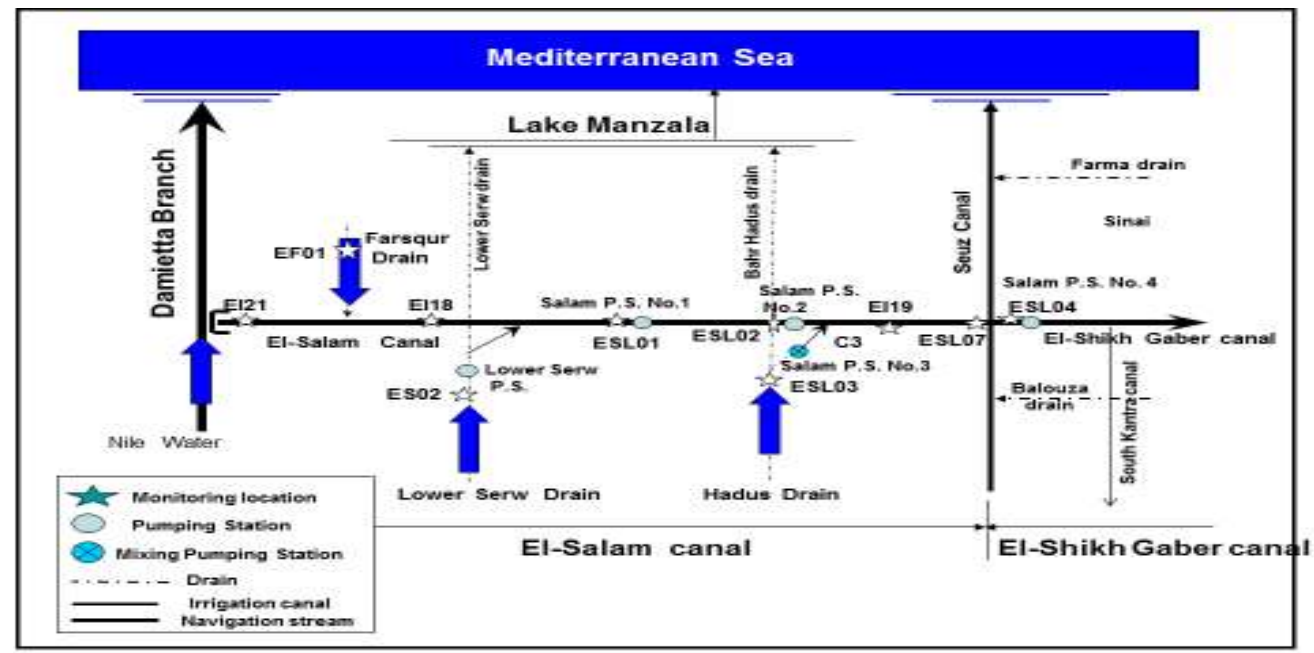

Figure (2): Schematic diagram of El Salam Canal with sample locations 
J. Environ. Sci.

Institute of Environmental Studies and Research - Ain Shams University

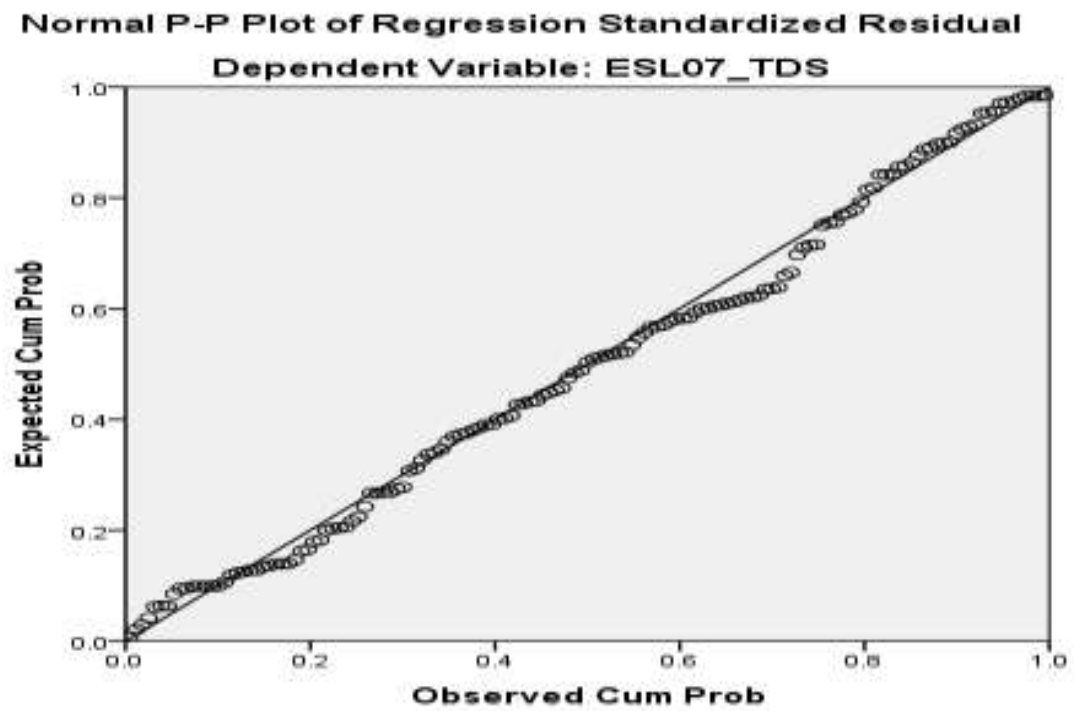

Figure (3): Normal Probability Plot of Regression Standardized Residual for TDS model

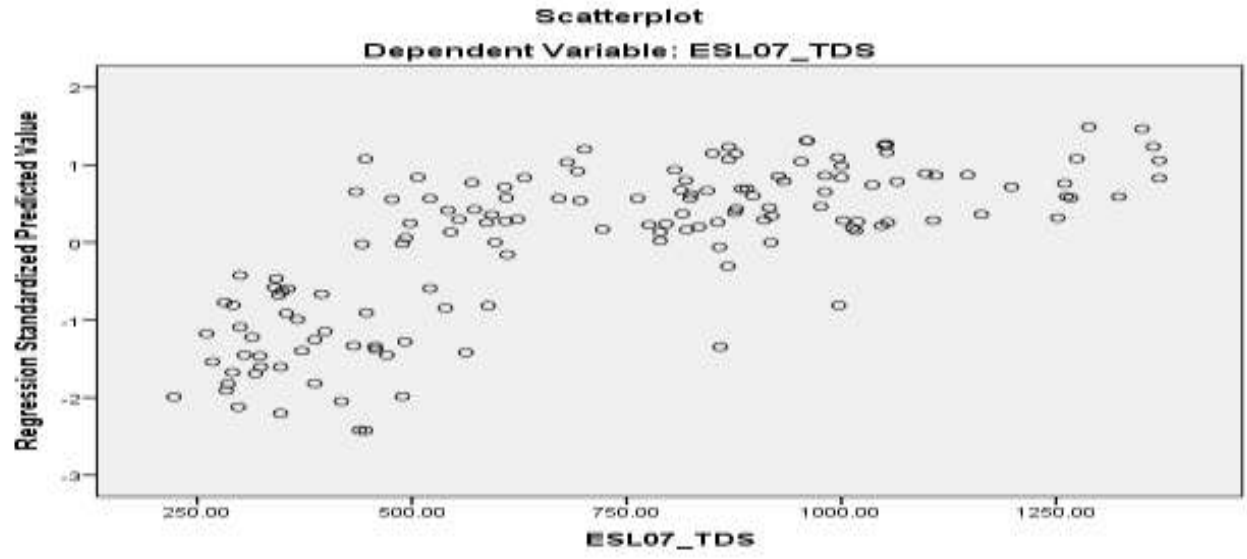

Figure (4): Plot of standardized residuals against standardized predicted values for TDS model 


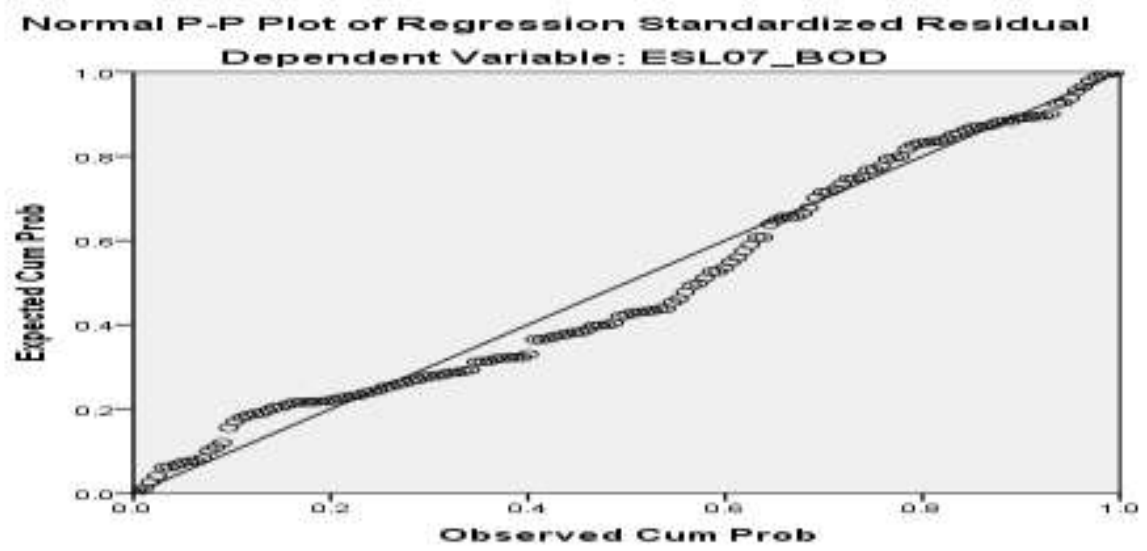

Figure (5): Normal Probability Plot of Regression Standardized Residual for BOD model

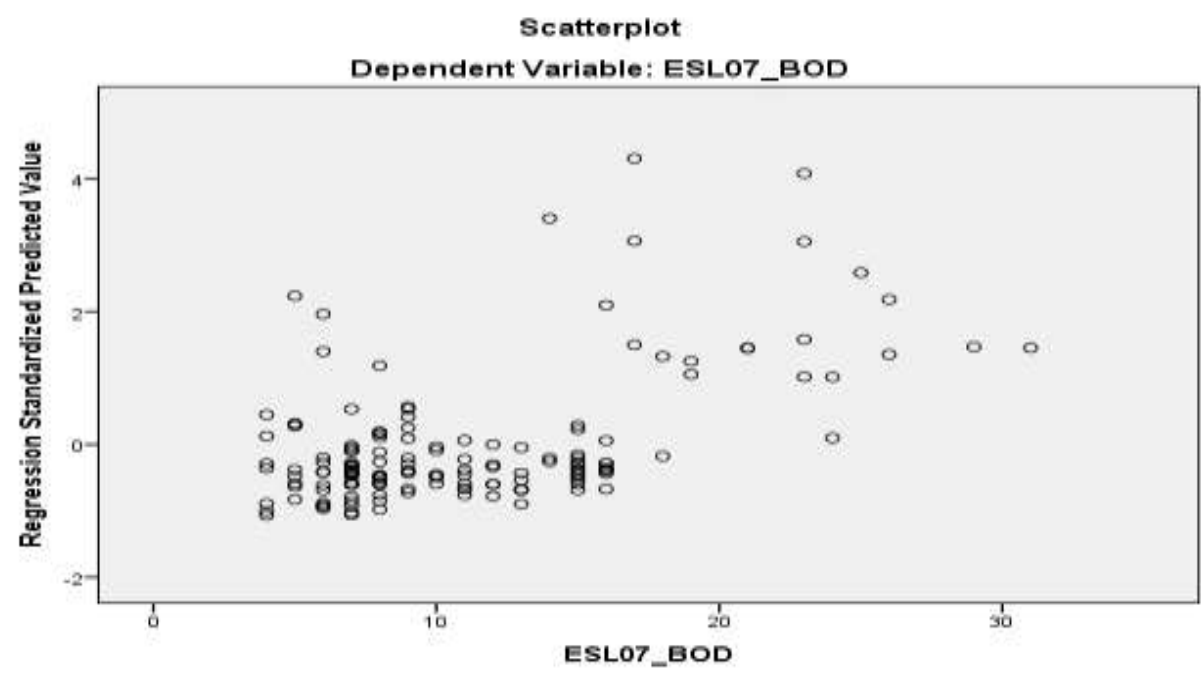

Figure (6): Plot of standardized residuals against standardized predicted values for BOD model 
J. Environ. Sci.

Institute of Environmental Studies and Research - Ain Shams University

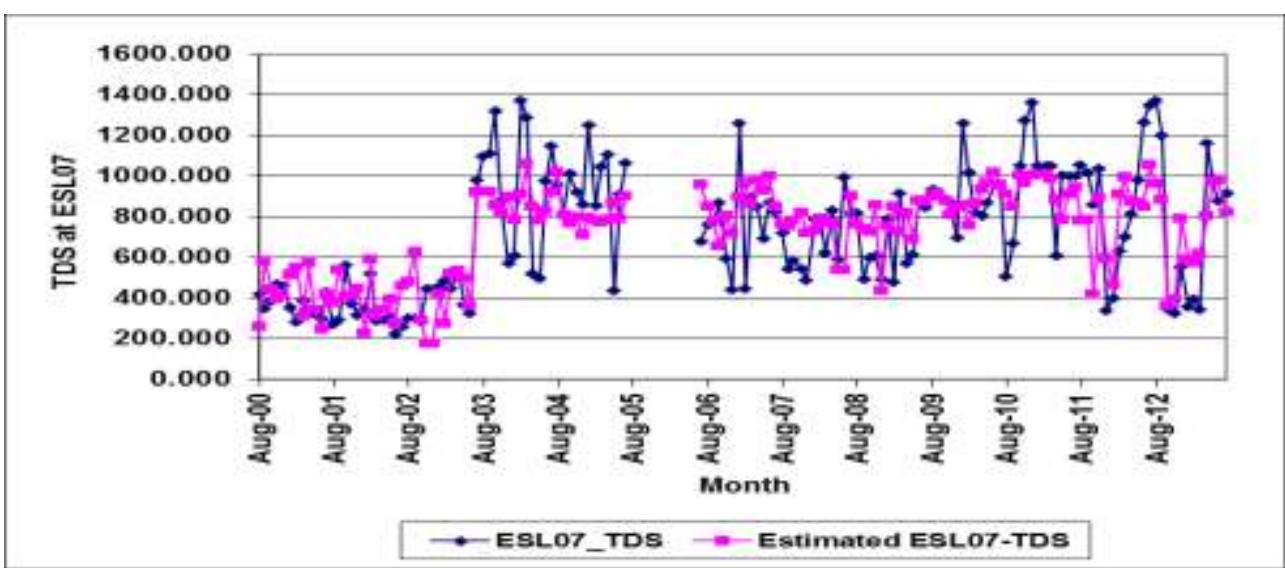

TDS Model (mg/l)

Figure (7): Simulated (Field /measured) data versus the prediction of TDS Model TDS Model III (mg/l)

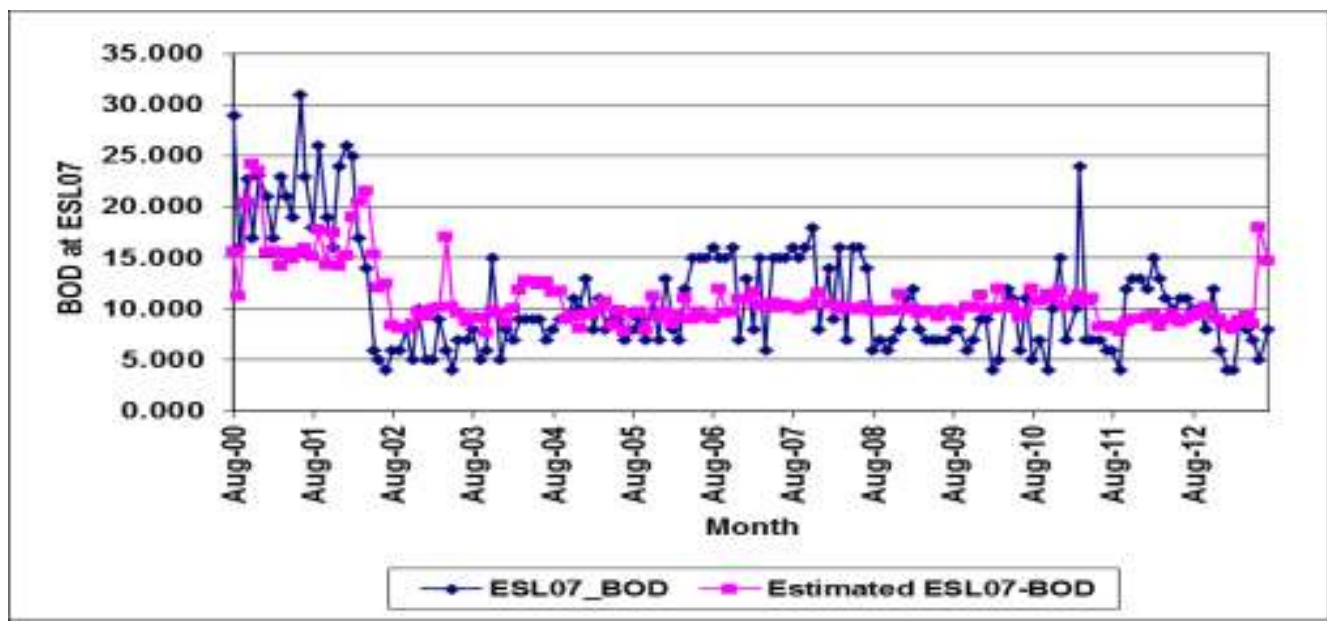

\section{BOD Model (mg/l)}

Figure (8): Simulated (field/measured) data versus the prediction of BOD Model 


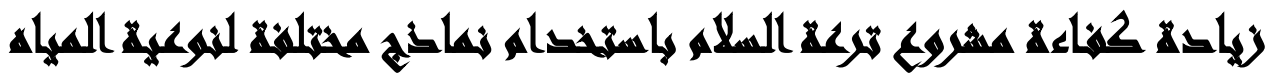

[1]

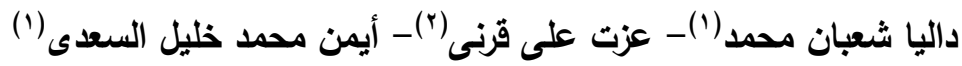

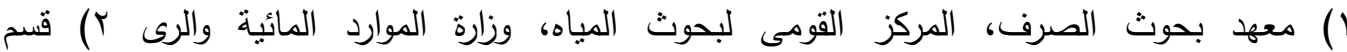

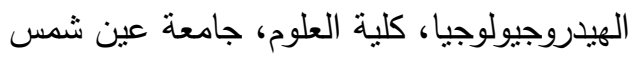

\section{linarist}

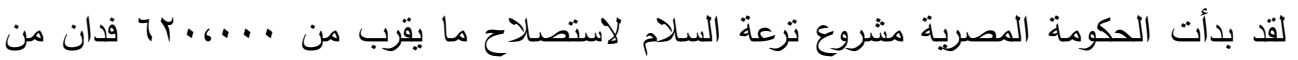

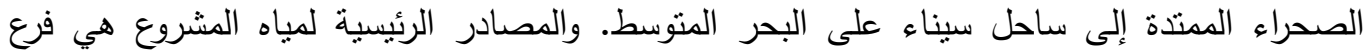

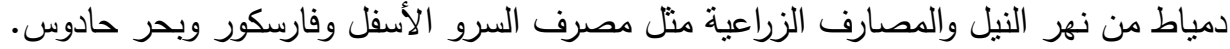

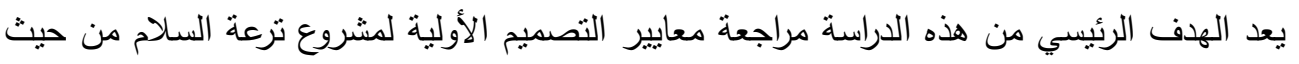

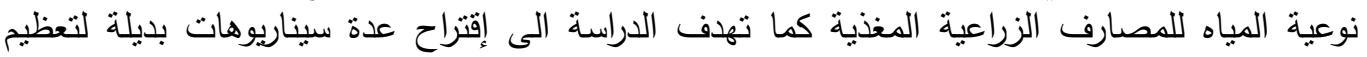

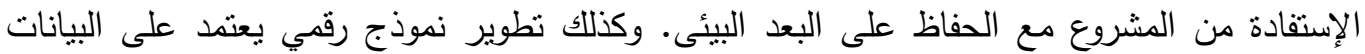

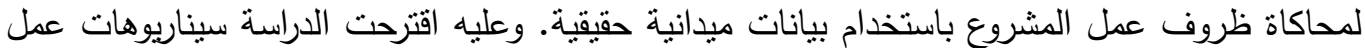
بديلة مقبولة من المنظور البيئي. بدأ التحليل من خلال تطولة البّير النموذج لبيانات جودة نوعية المياه التي تم جمعها شهريًا خلال الفترة

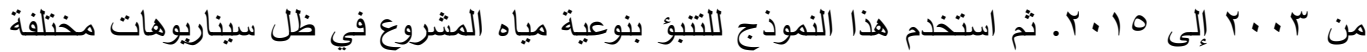
للعمل.

وقد نم التأكد من ان هذا النموذج يعمل بشكل جيد في التتبؤ بمقاييس نوعية المياه المختلفة (مثل

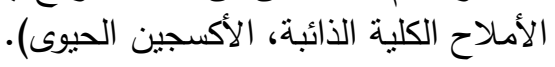

وقد نم عرض سيناريوهان لإدارة المياه من أجل النتغيل المستقبلي للمشروع و يشمل السيناريو الأول

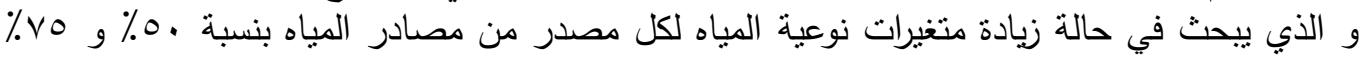

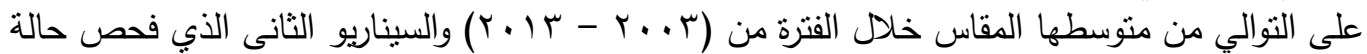

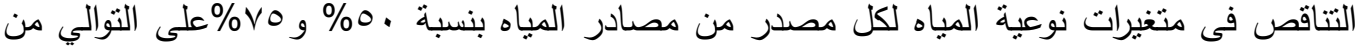

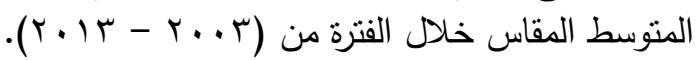

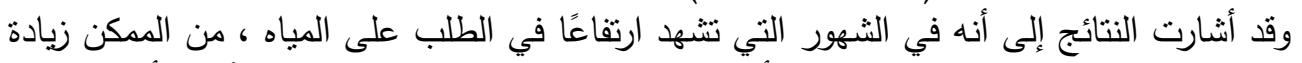

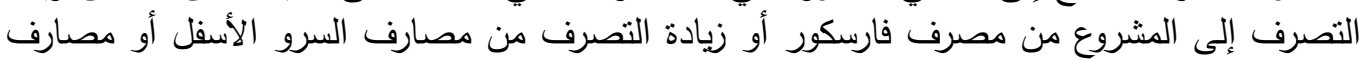
بحر حادوس على التوالي فى حالة الطلب على المياه ومدى نوافرها وكذلك بقاء مستويات تركيز نوعية 